\title{
潜在作物生産性モデルGAEZの北海道での適用 可能性の検討と改良
}

\author{
田中 朱美 ${ }^{1 *}$ 高橋 潔 ${ }^{2}$ 申 龍熙 ${ }^{2}$ 増冨 祐司 ${ }^{3}$ ・ \\ 山中 康裕 $^{4} \cdot$ 佐藤 友徳 $^{4}$ \\ ${ }^{1}$ 北海道大学 大学院環境科学院（ $\bar{T} 060-0810$ 北海道札幌市北区北10条西5丁目） \\ ${ }^{2}$ 国立環境研究所 社会環境システム研究センター（テ305-8506 茨城県つくば市小野川16-2） \\ 埼玉県環境科学国際センター 温暖化対策研究室（テ347-0115 埼玉県加須市上種足914） \\ ${ }^{4}$ 北海道大学 大学院地球環境科学研究院 ( $\bar{T} 060-0810$ 北海道札幌市北区北10条西5丁目) \\ * E-mail: a_tanaka@ees.hokudai.ac.jp
}

\begin{abstract}
現在気候下の北海道のコメ収量変動を再現するため, 潜在作物生産性モデルGAEZの北海道への適用可 能性評価および改良を実施した。改良前のGAEZでは計算対象期間の大半で北海道のほぼ全域で気温条件 を満たさず収量がゼロとなり, 耐冷性の強化によってコメ栽培が可能となった北海道にはそのまま適用で きなかった. モデルの改良として(1)気温条件の緩和, (2)バイオマス計算論理の変更, (3)出穂日推定論理 の追加，および(4)障害型冷害の考慮を実施した。(1)により寒冷地でも収量を得ることが可能となるが， 観測の収量変動をほとんど再現しなかった。(1)に加え(2), (3), (4)を組み合わせることで再現性は大幅に 向上した。特に障害型冷害の考慮と出穂日の推定が北海道の観測収量変動の再現性向上に大きく寄与した.
\end{abstract}

Key Words : paddy rice, Hokkaido, heading date, cool summer damage due to floral impotency, effective accumulated temperature

\section{1. はじめに}

気候変動に関する政府間パネル第4次評価報告書 （IPCC AR4）では，気温上昇による全球での作物生産 性について, 中・高緯度では 1 3 $\mathrm{C}$ の気温上昇で生産性 が向上する一方，低緯度では $122^{\circ} \mathrm{C}$ 気温上昇でも生産 性が減少し，上記以上の気温上昇では全地域で生産性が 減少すると予測している1)。主要作物の生産性は食料安 全保障等の観点からも重要であり，気候変動に対する脆 弱性や地域特性を把握することが求められている。この ような背景から，現在多くのモデルが開発され，気候変 動下の作物収量予測が行われている. Masutomi et al. ${ }^{2}$ は 潜在作物生産性モデルGAEZを改良し, 複数の気候変動 予測シナリオおよび排出シナリオを用いてアジア地域の コメ収量の定量的予測を行い，特に2080年代のA2シナ リオの場合に収量が著しく減少することを示した. 申ら 3)はMasutomi et al. ${ }^{2)}$ と同様の手法で全球を対象としたトウ モロコシの収量変化の定量的予測を行った.

日本における作物収量の評価について，横沢ら吕は広
域コメ収量予測機構モデルPRYSBIを用いて全国4地域の 気温上昇度に対するコメ収量変化を定量的に評価した。 モデルのパラメータを県単位で統計的に推定することに より国内の地域特性を反映した予測を実現し，北海道・ 東北地域は気温上昇に伴いコメ収量は増加するが，それ 以外の地域は減少することを示した。

IPCC AR4 ${ }^{1)}$ や横沢ら ${ }^{4)}$ の結果によると, 北日本ではコメ の増収が期待されるが，増収率や収量の安定性から作付 地域の選定等を行う際にはより地域詳細な予測が求めら れる. 特に我が国のコメ作付の北限である北海道では, たびたび冷害の被害に遭うなど気象条件による制約が大 きいため，気候変動下の収量予測やそれに基づいた栽培 適地の判定は重要である. 適地の変化による将来の作付 地域の変化が北海道の土地利用計画や食糧自給に与える インパクトは大きい.

以上のように，北海道における気候変動下のコメ収量 への影響評価は重要であるが，より信頼性の高い評価の ためには現在の北海道の気候に対する応答を再現できる か確認する必要がある。そこで，本研究では将来の気候 
変動による影響評価に適用寸ることを念頭にして, 北海 道を対象に現在気候下のコメ収量変動を再現し，その再 現性を評価することを目的とする．本研究では戋場スケ ールでの細かい品種別の気候感度より, 北海道内のコメ の気候に対する応答の地域差や収量分布を包括的に評価 したいため，ある程度広域に対応したプロセスモデルを

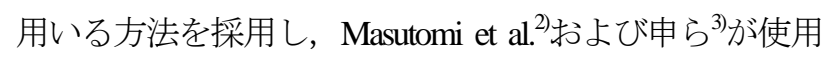
した広域モデルのGAEZを用いることとした，GAEZモ デルは気温等の条件により栽培に適しているかを判定す る適性判定条件を含む. 本研究ではこのような判定条件 を寒冷地である北海道に適用できるようにモデル改良を 行った. さらにバイオマス量の計算方法を変更の上，北 海道において甚大な被害をもたらし適地評価の観点から も重要な泠害リスクを反映できるようにした，本稿では GAEZモデルの北海道への適用可能性と改良の効果につ いて現在気候での観測収量の再現性に基づき評価する.

\section{2. モデルと実験設定}

本研究では Masutomi et al. ${ }^{2}$ による改良版の GAEZ (Global Agro-Ecological Zones) モデルを用いた. 元の GAEZ モデルは国際連合食糧農業機関（FAO）と国際応 用システム分析研究所（IIASA）により開発された潜在

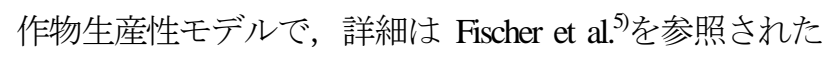
い. 以降では改良版 GAEZ モデルの概要および実験設 定について示す.

\section{(1) 潜在作物生産性モデルGAEZの概要}

表-1 に GAEZ モデルの入力データを示す. 元の気候
入力データは日平均気温 $\left[{ }^{\circ} \mathrm{C}\right]$, 日降水量 $[\mathrm{mm} / \mathrm{day}]$, 日平 均放射 $\left[\mathrm{W} / \mathrm{m}^{2}\right]$, 日平均風速 $[\mathrm{m} / \mathrm{s}]$, 気温日較差 $\left[{ }^{\circ} \mathrm{C}\right]$ である が，本研究では日較差の代わりに日最高気温 $\left.{ }^{\circ} \mathrm{C}\right]$ と日最 低気温 $\left[{ }^{\circ} \mathrm{C}\right]$ を用いた。

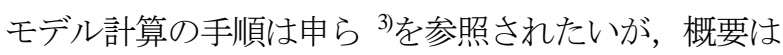
下記の通りである．まず入力の気候条件に基づき，気温 条件による適性判定, 成長期間の算出, および農業気象 制約を考慮した作物成長計算が行われる.さらに土壤制 約（土㙥の成分や傾斜など）, 灌泊面積率，入カレベル 等を考慮した収量が計算される。ここで入力レベルは各 国の資本や労働力，施肥等の社会経済要素を考慮した 高・中・低の 3 段階の要素で, 日本は高に該当する.

GAEZ モデルでは天水農地と灌泊農地（土袞水分の不足 による制約がないと仮定）について計算可能であるが， 日本では灌激なしで稲作を行っているとは考えにくいた め, 北海道全域で灌涀ありと仮定した。 以上により収量 ポテンシャル（北海道全域に作付した場合に見込まれる 収量）が得られ，実際の作付面積分布でマスクすること により作付地域のみの収量が得られる. GAEZ モデルで はさらに大気中 $\mathrm{CO}_{2}$ 濃度の変動による施肥効果を考慮可 能であるが，今回は現在気候下の計算であるため考慮し なかった。

コメについて, GAEZ モデルでは大きく乾燥地帯品種 と湿潤地帯品種に区別されており, 日本型イネは湿潤地 帯品種に分類される. デフォルトで日本型イネは成長期 間の異なる 4 つの品種（105，120，135，150日）の取扱 いが可能である. 計算は植付日および品種を固定した計 算と固定しない計算が可能で，固定しない場合は年毎に 収量が最大となる植付日および品種が選択される. 北海 道を対象とした計算では，観測収量変動との比較のため

表-1 GAEZモデルの入力データ

\begin{tabular}{|c|c|}
\hline GAEZ 入力項目名 & 北海道適用時の使用データ \\
\hline $\begin{array}{l}\text { 気候データ } \\
\text { 日平均気温 }\left[{ }^{\circ} \mathrm{C}\right] \text {, 日降水 } \\
\text { 量 }[\mathrm{mm} / \mathrm{day}, \text { 日平均放 } \\
\text { 射 }\left[\mathrm{W} / \mathrm{m}^{2}\right] \text {, 日平均風速 } \\
{[\mathrm{m} / \mathrm{s}] \text {, 気温日較差 }\left[{ }^{\circ} \mathrm{C}\right]}\end{array}$ & $\begin{array}{l}\text { 日平均風速以外 : } \\
\text { アメダスメッシュ化データ }{ }^{0} \\
\quad \text { (気温日較差は日最高気温 }\left[{ }^{\circ} \mathrm{C}\right] \text { と日最低気温 }\left[{ }^{\circ} \mathrm{C}\right] \text { から算出） } \\
\text { 日平均風速 : } \\
\text { JRA-25長期再解析データ }{ }^{7} \text { \&RF（Weather Research and Forecasting ）モデル }{ }^{8)} \\
\text { によりダウンスケール }\end{array}$ \\
\hline 行政区域界 & 国土数值情報 ${ }^{9)}$ \\
\hline 土壌タイプ & Digital Soil Map of the World ${ }^{10)}$ \\
\hline 標高 & GTOPO30 \\
\hline $\begin{array}{l}\text { 作付面積 } \\
\text { 灌㵿面積率 }\end{array}$ & $\begin{array}{l}\left.\left.\text { 作物統計（農林水産省） }{ }^{12) 13}\right) \text { ，北海道農林水産統計年報 }{ }^{14)} \text { ，国土数值情報 }{ }^{15}\right) \\
\text { 使用しない（全域で灌溉ありと仮定） }\end{array}$ \\
\hline $\begin{array}{l}\text { 肥料使用量（入カレベル } \\
\text { の算出に使用） }\end{array}$ & World Development Indicators $^{16)}$ \\
\hline
\end{tabular}


後述の方法で植付日と品種を固定して計算を行った.

\section{(2) 気候デ一タ作成方法}

GAEZモデルの入力として必要な気候データのうち, 日平均風速以外の要素は農業環境技術研究所作成のアメ ダスメッシュ化データのを使用した。 日平均風速はJRA25長期再解析デーダを領域気象モデルWRF（Weather Research and Forecasting) ${ }^{8}$ により力学的にダウンスケール したものを使用した．アメダスメッシュ化データは3次 メッシュ（約 $1 \mathrm{~km}$ 格子），WRFデータは10km格子出力で ある. 本研究では北海道全域を $0.05^{\circ}($ 約 $5 \mathrm{~km})$ 格子で解 像するため, アメダスメッシュ化データは単純平均によ り平滑化し, WRFデータは近傍4点による逆距離加重平 均法にて線形内挿し使用した。

\section{（3）行政区域データ・作付面積データ作成方法}

行政区域（旧支庁・市町村）は国土数值情報の平成22 年度の行政区域界データ9を 0.05 格子で解像し使用した。 行政区域に基づくデータ作成および解析は全て平成22年 度の状態（14支庁・179市町村）に従い実施し，それ以 前の合併等による変動は考慮しない，また，旧支庁は現 在の総合振興局・振興局を指寸が，以降本文では支庁と 記載する.

観測収量変動の再現性評価には作付面積に基づく収量

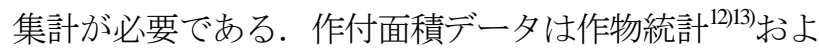
び北海道農林水産統計年報 ${ }^{14}$ の市町村別耕地面積・作付 面積データと国土数值情報の土地利用3次メッシュ ${ }^{15}$ を もとに下記手順で作成した.

1) 国土数值情報 ${ }^{15}$ の田耕地面積分布データを $0.05^{\circ}$ 格子で 投影し，市町村別に集計する．データは1987年，1991 年，1997年，2006年のものを使用し，各々について上 記作業を実施する.

2) 各市町村について, 統計值 ${ }^{1214}$ の毎年の市町村別田耕 地面積データと1)で作成した市町村別集計データの比 を算出し，1)の0.050格子の分布データに比を乗算する。 これは耕地面積の分布は国土数值情報に従っており, 市町村毎の面積集計值は統計值により補正されること を意味する．統計值のみ值ありの場合は当該市町村内 の格子に統計值の耕地面積を割り当て, 国土数值情報 のみ值ありの場合は統計值に従い面積ゼロとした．計 算対象期間は1985年〜2005年とし，国土数值情報の 1987年データを1985年〜1989年に，1991年データを 1990年～1994年に，1997年データを1995年～2001年に， 2006年データを2002年〜2005年にそれぞれ対応させ， 各年のデータを作成した。

3) 各年に対し市町村毎に統計值 ${ }^{12131314}$ の田耕地面積デー タと作付面積データの比を算出し，2)で補正した耕地

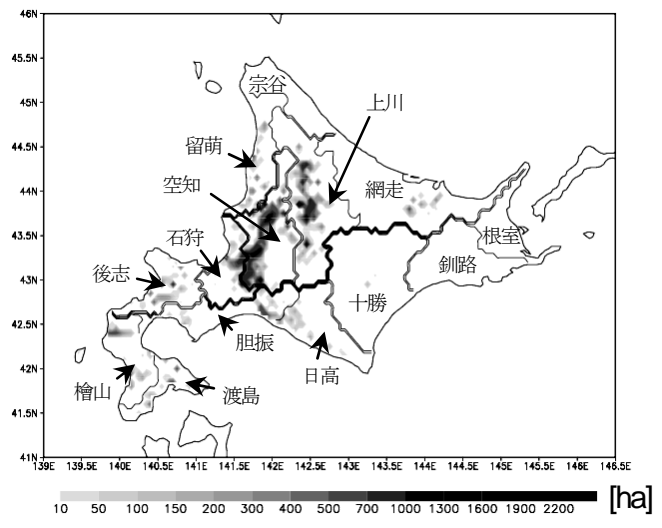

図-1２000年の作付面積分布と支庁の位置

表-2 4地域分類と支庁の対応関係

\begin{tabular}{l|l}
\hline 地域名称 & 支庁名 \\
\hline 札幌 & 留萌, 上川, 空知, 石狩 \\
函館 & 後志, 胆振, 檜山, 渡島 \\
帯広 & 日高, 十勝, 釧路 \\
北見 & 根室, 網走, 宗谷 \\
\hline
\end{tabular}

表-3 本研究の実験設定

\begin{tabular}{|c|c|}
\hline 項目 & 設定内容 \\
\hline モデル & GAEZ モデル \\
\hline 対象期間 & 1985年～2005年（21年間） \\
\hline 対象領域 & $\begin{array}{l}139^{\circ} \mathrm{E} \sim 146.5^{\circ} \mathrm{E}, \quad 41^{\circ} \mathrm{N} \sim 46^{\circ} \mathrm{N} \\
\text { (北海道全域) }\end{array}$ \\
\hline 解像度 & 東西 $0.05^{\circ} \times$ 南北 $0.05^{\circ}$ \\
\hline 対象作物 & 日本型イネ（成長期間 128 日） \\
\hline 植付日 & 4地域毎に固定 \\
\hline 気候条件 & $\begin{array}{l}\text { 日平均気温 }\left[{ }^{\circ} \mathrm{C}\right] \text {, 日最高気温 }\left[{ }^{\circ} \mathrm{C}\right] \text {, 日 } \\
\text { 最低気温 }\left[{ }^{\circ} \mathrm{C}\right] \text {, 日平均放射 }\left[\mathrm{W} / \mathrm{m}^{2}\right], \text { 日 } \\
\text { 降水量 }[\mathrm{mm} / \mathrm{day}] \text {, 日平均風速 }[\mathrm{m} / \mathrm{s}]\end{array}$ \\
\hline
\end{tabular}

面積分布データに乗算したものを作付面積分布データ とする.

図-1は以上により作成した2000年における作付面積分 布と支庁の位置である．全計算対象期間を通して作付面 積は空知支庁，上川支庁に集中寸るほか，北海道西部や 十勝・網走地方に点在する。一方，宗谷・釧路・根室支 庁では作付面積はゼロである.

(4) 観測耕種期日・品種および収量データ

本研究では観測収量変動の再現性を評価するため，植 付日および品種を観測に基づき固定して計算を行った. 

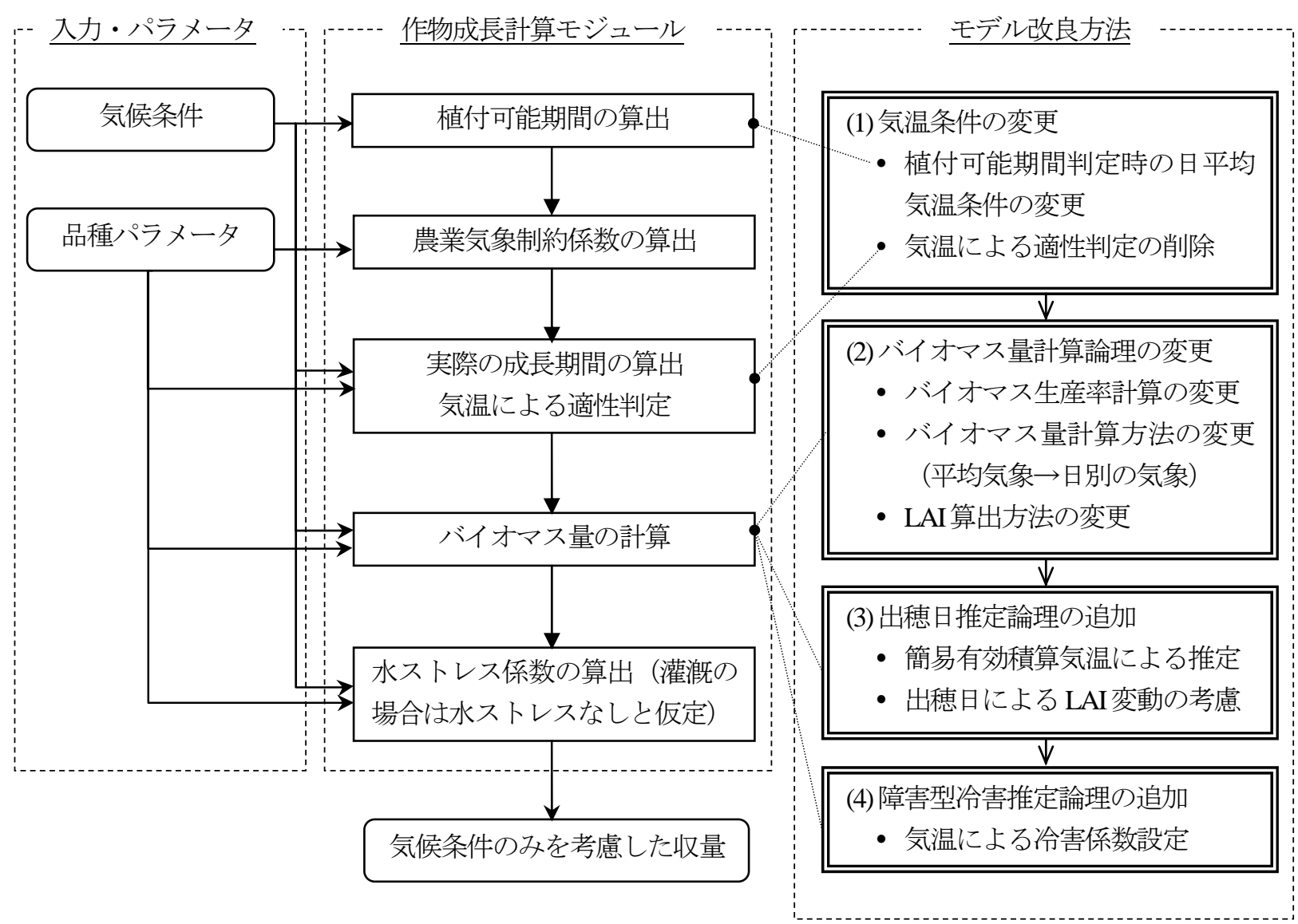

図-2 作物成長計算の流れとモデル改良方法

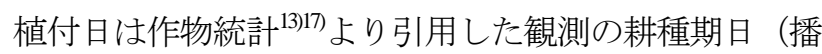
種期，移植期，出穂期，刈取期）のうち移植期を設定し た. 耕種期日は北海道内を4地域（札幌，函館，帯広， 北見）に分類し収録されているため，植付日もこの4地 域毎に設定した。支庁と4地域の対応関係は表-2に示す 通りである. 品種については観測の耕種期日に従い成長 期間の調整を実施した。GAEZモデルでは直播栽培を想 定し成長期間を4つの生育ステージ（initial， crop development, mid-season, late season ; 本稿では順にini, dev, mid, end期と略す）に分類している. 元の設定では各ス テージの成長期間に占める比率[\%]はini， dev， mid，end 期の順に10，30，30，30であった。本研究では移植日を dev期始め, 出穂日をmid期末日と仮定し，4地域毎の計 算対象期間での観測移植期〜刈取期および移植期〜出穂 期の平均日数をさらに各々4地域で平均した日数（約 129.8日および約71.5日）をもとに，ini， dev， mid，end期 の比率[\%]を20，30，15，35とし， dev期〜end期を128日 （ini期〜end期で160日）とした。本研究では移植期を植 付日としたため，収量計算等に用いる成長期間はdev期 〜end期の128日と設定した. 成長期間以外の品種固有の パラメータはGAEZモデルの成長期間150日の品種と同様 とした。 ini期〜 dev期（播種〜移植期の想定）でのバイ
オマス生産量（移植時の乾物重）は最終収量の $1 / 100 の$ オーダー程度と想定されるため，今回は考慮しなかった。 なお，上記品種設定は北海道全域で同一の值とした。

再現性評価の際に使用する観測収量データは作物統計 12)13)および北海道農林水産統計年報 ${ }^{14)}$ の市町村別収量デ ータ（[kg/10a]）を用いた。

\section{(5) 実験設定}

以上の計算手順・データにより，北海道を対象にコメ 収量のシミュレーションを実施した．実験設定は表-3の 通りである。再現性評価は観測収量年変動とGAEZモデ ル出力の収量年変動との比較により実施した。 その際, GAEZモデル出力の収量は作付面積で重み付け集計した 值を用いた.

GAEZモデルの北海道への適用可能性を評価するため, モデルの改良を実施した。改良方法は3章に示す通りで ある. 改良前と改良後の観測収量変動の再現性を比較す ることで，改良の効果を定量的に評価した４章ではそ の結果について述べる. 


\section{3. モデル改良方法}

本研究では, GAEZモデルの作物成長計算モジュール （気候条件のみを考慮した収量を計算）について改良を 行った. 作物成長計算モジュールの流れと改良方法の対 応は図-2の通りで，モデルの改良は4段階で実施した。

下記に各段階の改良方法について示寸.

\section{(1) 気温条件の変更}

作物成長計算モジュールでは，まず気候条件をもと に植付可能期間の算出を行う。10年間のスピンアップ計 算後, 積雪, 降水および土壌水分の状態, 日平均気温条 件により各日について植付可否，休眠状態（日本型イネ の場合考慮しない）について判定し, 植付可能と判定さ れた日が連続する期間を植付可能期間と設定する。この うち日平均気温は $5^{\circ} \mathrm{C}$ 以上が条件であったが，北海道東 部一帯で実際には平年以上の収量であった1989年に,

GAEZモデルでは条件を満たさず収量がゼロと判定され た.この条件は栽培適地判定の観点に基づくもので, 北 海道に適した值を決定するため $4^{\circ} \mathrm{C}, 3^{\circ} \mathrm{C}$ よび $0{ }^{\circ} \mathrm{C} て ゙$ 感 度分析を行った．観測収量の再現性を吟味した結果，本 研究ではこの条件を $4{ }^{\circ} \mathrm{C}$ に緩和することとした。

GAEZモデルでは，上記で設定した植付可能期間と品 種パラメータの成長期間を照合し実際の成長期間の算出 が行われる. その後, 気温による適性判定が行われ，適 性と判定された場合のみ収量計算が行われる. 気温によ る適性は成長期間内の積算気温や各気温帯 $\left(10^{\circ} \mathrm{C}\right.$ 以上 $15^{\circ} \mathrm{C}$ 未満など）日数の成長期間に占める割合から判定さ れるが，北海道に適用すると多くの年にほぼ全域で条件 を満たさなかった。これは主に低温に関する条件 $\left(10^{\circ} \mathrm{C}\right.$ 以上 $20^{\circ} \mathrm{C}$ 未満の日数および $10^{\circ} \mathrm{C}$ 未満の日数）を満たさな いことによる. 北海道は品種の耐冷性を強化しコメ作り が可能となった地域であるため, 全球スケールの判定条 件をそのまま適用できない，今回はこの気温判定条件を 撤廃し，収量を算出することとした。

\section{(2) バイオマス量計算論理の変更}

バイオマス量は，光合成率（日中気温等に依存）に関 連づけられたバイオマス生産率と呼吸率（日平均気温等 に依存）に基づいて計算される．詳細はGAEZモデルの 当該項目の説明書 ${ }^{18)}$ を参照されたい. 今回用いたGAEZ モデルではバイオマス生産率に関わる日射量の取り扱い について説明書と異なる計算式を用いていたが，北海道 へ適用する際に説明書に準ずる式に変更した. 寸なわち, バイオマス生産率は下記により計算される.

$$
b_{g m}=\left\{\begin{array}{c}
F\left(0.8+0.01 P_{m}\right) b_{o} \\
+(1-F)\left(0.5+0.025 P_{m}\right) b_{c} \\
\text { for } P_{m}>20 \\
F\left(0.5+0.025 P_{m}\right) b_{o} \\
+(1-F)\left(0.05 P_{m}\right) b_{c} \\
\text { for } P_{m} \leq 20
\end{array}\right.
$$

ここで $b_{g m}$ は最大総バイオマス生産率, $P_{m}$ は最大光合 成率， $b_{o}$ は完全に晴りの日の総乾物生産率， $b_{c}$ は快晴 日の総乾物生産率を指寸Ｆ注日中の空に占める雲の 比で, $F=\left(A_{c}-0.5 R_{g}\right) /\left(0.8 A_{c}\right)$ により算出される ( $A_{c}$ は晴天時の最大有効短波放射 $\left[\mathrm{calcm}^{-2} \mathrm{day}^{-1}\right]$ で, 光合 成有効放射を用いた。 $R_{g}$ は下向き短波放射 $\left[\mathrm{calcm}^{-2} \mathrm{day}^{-1}\right]$ を指す）。

GAEZモデルでは成長期間の平均気象を用いて成長曲 線の変曲点での光合成率やバイオマス生産率, 呼吸率を 算出し, 成長期間の平均バイオマス生産率を変曲点での 生産率の $1 / 2$ と仮定し正味のバイオマス生産量を計算す るが，北海道へ適用する際，日々の気象を用いるように 変更した．具体的には，必ずしも正確ではないが，平均 気象による各々の計算式が日々の気象に対しても成立す ると仮定し，日々のバイオマス生産率および呼吸率を求 め，成長期間で積算するようにした，これは日毎に成長 曲線を描きバイオマス生産量を求めることに相当する. これにより最終的な正味のバイオマス生産量および収量 ポテンシャルは下記により計算される.

$$
\begin{gathered}
b_{n, i}=\left(0.36 b_{g m, i}-0.5 c_{t, i} \sum_{j}^{i-1} b_{n, j}\right) \times L_{i} \\
B_{n}=\sum_{i}^{N} b_{n, i} \\
Y_{p}=B_{n} \times H \times N / N_{0}
\end{gathered}
$$

ここで添え字 $i$ は各日を表し， $b_{n, i}$ は各日の正味のバイ オマス生産量を表す， $c_{t, i}$ は呼吸に関する係数， $L_{i}$ は 葉面積指数（LAI）から算出される係数である. $N$ は 実際の成長期間で, $B_{n}$ は成長期間全体での正味のバイ オマス生産量を表す。最終的な収量ポテンシャル $Y_{p}$ は 正味のバイオマス生産量に収穫指数 $H$ および品種固有 の成長期間 $N_{0}$ を考慮した值となる.

(2)式において， $L_{i}$ を算出するためにLAIを日々推定す る必要がある. 今回のモデル改良では，FAO ${ }^{19}$ による作 物係数推定方法および桜谷・堀江 ${ }^{20}$ による蒸発散量と LAIの関係式を用いて日々のLAIを推定した，桜谷・堀 江 $^{20}$ によれば水田蒸発散量を $E T$, 水面蒸発量を $E$ と したとき，LAIとの関係は下記の式で表される. 


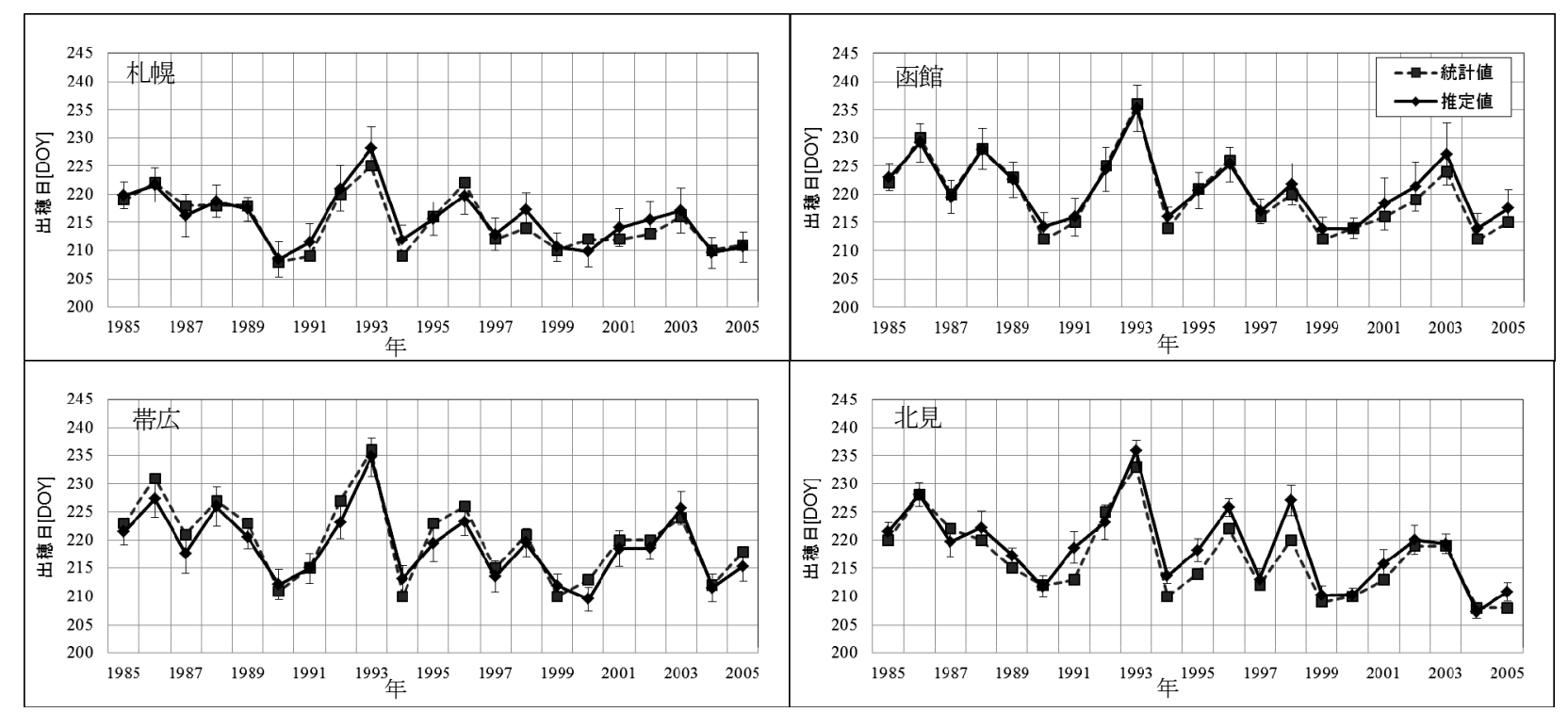

図-3 簡易有効積算気温による出穂日推定值の地域別平均と統計值の比較. 推定值はモデル改良手順の(1)〜(3)までを適用し た場合に収量がゼロ以外の格子の出穂日を平均した值. エラーバーは各地域に含まれる格子の出穂日推定值の標準偏 差を表す.

$$
\frac{E}{E T}=e^{-k L A I}
$$

ここで係数 $k$ は 0.40 である. $\mathrm{FAO}^{19)}$ による作物係数推定 方法によれば，蒸発散量は基準蒸発散量 $E T_{0}$ （ペンマ ン・モンティース法により日々推定）に作物係数 $K_{c}$ を 乗算して得られ，下記が成り立つ。

$$
E T=\left(K_{c b}+K_{e}\right) E T_{0}=K_{c} E T_{0}
$$

ここで $K_{c b}$ は基礎作物係数, $K_{e}$ は土畩蒸発係数である. $E=K_{e} E T_{0}$ と考えられることから，(5)は下記のよう に変換できる.

$$
\frac{E}{E T}=\frac{K_{e}}{\left(K_{c b}+K_{e}\right)}=e^{-k L A I}
$$

本研究では作物係数推定方法に従い $K_{c b}$ および $K_{e}$ を推 定し，(7)を用いてLAIを算出した．詳細はFAOによる説 明書 ${ }^{19}$ を参照されたいが，概要は下記の通りである。ま ずini, dev, mid, endの4つの作期各々について $K_{c b}$ を算 出する. 本研究ではGAEZモデルのパラメータとして設 定されている $K_{c}$ とFAOによる説明書 ${ }^{19}$ を勘案し, ini, mid，end期の $K_{c b}$ をそれぞれ0.9，1.15，0.7とした． mid 期と end期の $K_{c b}$ は各期間の平均風速, 平均日最低相対 湿度, 平均作物長により補正する. $\operatorname{dev}$ 期の $K_{c b}$ はini期 の值を起点, mid期の值を終点として日々単調増加し, end期はmid期の值を起点，end期の值を終点として単調 減少するように設定する. 次に, 下記により $K_{e}$ を算出
する.

$$
K_{e}=\min \left(K_{r}\left(K_{c \max }-K_{c b}\right), f_{e w} K_{c \max }\right)
$$

ここで $K_{c \max }$ は $K_{c}$ の上限值で平均風速や平均最低相 対湿度などを考慮した值である. $f_{e w}$ は露出した湿地の 比で, $f_{e w}=\min \left(1-f_{c}, f_{w}\right)$ により計算する. $K_{r}$ は 蒸発減衰係数（完全に湿っているとき1.0）， $f_{w}$ は灌溉 等により湿った土畩の比で，いずれも1.0とした. $f_{c}$ は 作物により被覆された土䱋の比で, $K_{c b}$ 等を考慮し算 出した，なお，平均風速および平均日最低相対湿度につ いて, 説明書 ${ }^{19}$ に記載のある上限・下限值は考慮しなか った．以上の算出で用いたdev, mid, end期の作物長は 平成21年度北海道立中央農業試験場年報 21 による北海道 品種「きらら397」，「ほしのゆめ」および「ななつぼ し」の平年の移植時，6月20日，7月20日の草丈および棹 長平均を線形内挿したものを使用した.

\section{(3) 出穗日推定論理の追加}

北海道の水稲移植栽培では安定生産をはかるために作 付品種の基準が作成されている (丹野ら ${ }^{22}$ ), 北海道ほ か 23)）.1989年より導入された基準では出穂日を基準と した気温条件から安全出穗期間（早限出穂期～晚限出穂 期）を設定し，簡易有効積算気温から推定した出穗日が 安全出穂期間内となるような品種を選定する．2008年に 導入された方法では, 水稲生育システムを用いて発育速 度を計算することにより出穂日を推定し, 安全出穂期間 を求めている，上記のいずれの方法でも，出穂日を予測 
することが水稲生育の予測において重要であることが示 唆されるが, GAEZモデルでは出穂日の推定論理は含ま れていない. このため, 新たに出穂日を推定する論理を 追加することとした.

本研究では簡易有効積算気温による出穂日推定論理を 採用した。 簡易有効積算気温とは, 日最高最低平均気温 から稲の生育に有効な温度（簡易有効気温）だけ使用し た積算值である (北海道ほか $\left.{ }^{23}\right)$ ），丹野ら 22)は簡易有効 気温 $\theta$ を下記により計算している.

$$
\theta=(a-b) /\left(1+\left(T_{\text {mean }} / c\right)^{b}+d\right)
$$

ここで， $a ， b ， c ， d$ はそれぞれ55.89942，-4.165141， 21.84576, 0.9107297で， $T_{\text {mean }}$ は日平均気温である. 本 研究でも(9)を用いて $\theta$ を算出した. $T_{\text {mean }}$ について, 丹 野ら 22) は日平均風速および日照時間を考慮した值を用い ているが，簡略化のため入力の日最高気温と日最低気温 の平均值を設定することとした.

植付日から $\theta$ を積算し, 基準值に達した日を出穗日

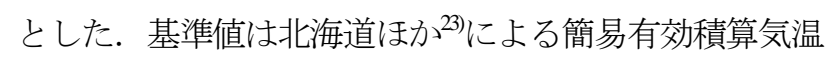
と晚限指標品種との対応関係をもとに4地域分類で調 整・設定し, 中生のうるち米品種が主の札幌・函館地域 は950 $\mathrm{C}$, 早生のもち米が主の支庁を含む帯広・北見地 域は $850^{\circ} \mathrm{C}$ とた。 図-3は4地域毎に平均した出穂日推定 值の統計值 ${ }^{13117}$ との比較である. 年・地域により誤差に ばらつきはあるが，二乗平均平方根誤差（RMSE）は札 幌，函館，帯広，北見の順に1.75，1.58，2.35，2.91[日]で， 概ね3日以内の精度で出穂日を予測できる.

イネのLAIは出穂日付近で最大となることから, 先述 のLAI算出方法に出穂日による恋動を考慮した. GAEZ の設定ではini， dev， mid，end期の成長期間に占める割 合は固定であったが， $K_{c b}$ を求める際に出穂日がmid期 末日となるようにし, dev, end期の割合を可変とした. すなわち, GAEZ設定のmid期末日より出穂が早い場合 はdev期の割合が減少し，その分end期の割合が増加する。 出穂が遅い場合はdev期の割合が増加し, end期の割合が 減少する.ただしend期が減少する場合， $K_{c b}$ は本来の end期間日数から算出するとした。これはLAIが成長期間 内に成熟期の值まで減少しきらないことを表す，さらに 出穂遅延による成熟不良を想定し, end期が減少する場 合は最終収量（(4)式の $Y_{p}$ ) にGAEZ設定のend期間に対 寸る実際のend期間の比を乗算した，なお，成長期間内 に出穂しない場合は収量ゼロとした。

\section{（4）障害型冷害推定論理の追加}

冷害は低温障害で不稔粐多発により減収する障害型と 低温による生育遅延で減収する遅延型，および両者の併
表-4 障害型冷害の不稔歩合[\%]. 北海道ほか ${ }^{24}$ による不稔 歩合の低位值を引用. ただし網掛け部分は本研究に よる拡張である.

\begin{tabular}{|c|c|c|c|c|c|}
\hline \multirow{2}{*}{$\begin{array}{l}\text { 前歴期 } \\
\text { 間 平均 } \\
\text { 気温 }\left[{ }^{\circ} \mathrm{C}\right]\end{array}$} & \multirow{2}{*}{$\begin{array}{l}\text { 危 険 期 } \\
\text { 間 平 均 } \\
\left.\text { 気温 }{ }^{\circ} \mathrm{C}\right]\end{array}$} & \multicolumn{4}{|c|}{ 開花期間最高気温 $\left.{ }^{\circ} \mathrm{C}\right]$} \\
\hline & & $<20$ & $<21$ & $<23$ & $\geqq 23$ \\
\hline$<16$ & $\begin{array}{l}<16 \\
<17 \\
<18.2 \\
<19 \\
\geqq 19 \\
\end{array}$ & $\begin{array}{l}100 \\
100 \\
90 \\
70 \\
65 \\
\end{array}$ & $\begin{array}{l}100 \\
92.5 \\
82.5 \\
57.5 \\
47.5 \\
\end{array}$ & $\begin{array}{l}100 \\
90 \\
80 \\
37.5 \\
22.5\end{array}$ & $\begin{array}{l}100 \\
90 \\
77.5 \\
27.5 \\
12.5 \\
\end{array}$ \\
\hline$<18$ & $\begin{array}{l}<16 \\
<17 \\
<18.2 \\
<19 \\
\geqq 19 \\
\end{array}$ & $\begin{array}{l}100 \\
92.5 \\
82.5 \\
57.5 \\
47.5 \\
\end{array}$ & $\begin{array}{l}92.5 \\
85 \\
75 \\
45 \\
30 \\
\end{array}$ & $\begin{array}{l}90 \\
80 \\
65 \\
25 \\
5 \\
\end{array}$ & $\begin{array}{l}90 \\
80 \\
60 \\
20 \\
5 \\
\end{array}$ \\
\hline$\geqq 18$ & $\begin{array}{l}<16 \\
<17 \\
<18.2 \\
<19 \\
\geqq 19\end{array}$ & $\begin{array}{l}95 \\
85 \\
72.5 \\
57.5 \\
47.5 \\
\end{array}$ & $\begin{array}{l}85 \\
75 \\
55 \\
45 \\
30\end{array}$ & $\begin{array}{l}80 \\
70 \\
40 \\
25 \\
5\end{array}$ & $\begin{array}{l}77.5 \\
65 \\
35 \\
20 \\
5\end{array}$ \\
\hline
\end{tabular}

行型の3つに区分される (北海道ほか24) ）。出穗日を推 定しLAIを変動させる方法は遅延型冷害を想定しており 障害型の冷害は考慮していないため, さらに論理追加を 行った。北海道ほが24では障害型冷害の影響を受けやす い前歴期間，冷害危険期間，開花期間の気温分類による 北海道品種「きらら397」の不稔歩合推定を行っている. 本研究ではこの推定不稔歩合[\%]を利用し，（1-不稔歩 合/100）を冷害係数として収量ポテンシャルに乗算する ことで障害型冷害の影響を考慮することとした．表-4に 今回設定した各期間の気温分類による不稔歩合推定值を 示寸. 前歴期間は出穂前24～15日，冷害危険期間は出穂 前14〜8日，開花期間は出穂後7日間とした．また，推定 元の北海道ほか ${ }^{24}$ の注釈に従い, 5 15\%の不稔発生は収 量ポテンシャルに影響しない（冷害係数=1）とした.

\section{4. 結果と考察}

はじめに，各改良方法の効果について示す．改良方法 (1)の実施により, 北海道のほぼ全域で収量が計算され るようになった. 収量の平均值は観測収量と近いが, 年々変動はほとんどみられず観測収量の再現性は低かっ た. (2)のバイオマス生産率計算の変更により年々変動 はやや大きくなったが, 収量は大幅に過大となった。 (2)の残りの手順を行うことで収量の過大傾向は緩和さ 
(1) 1993 年
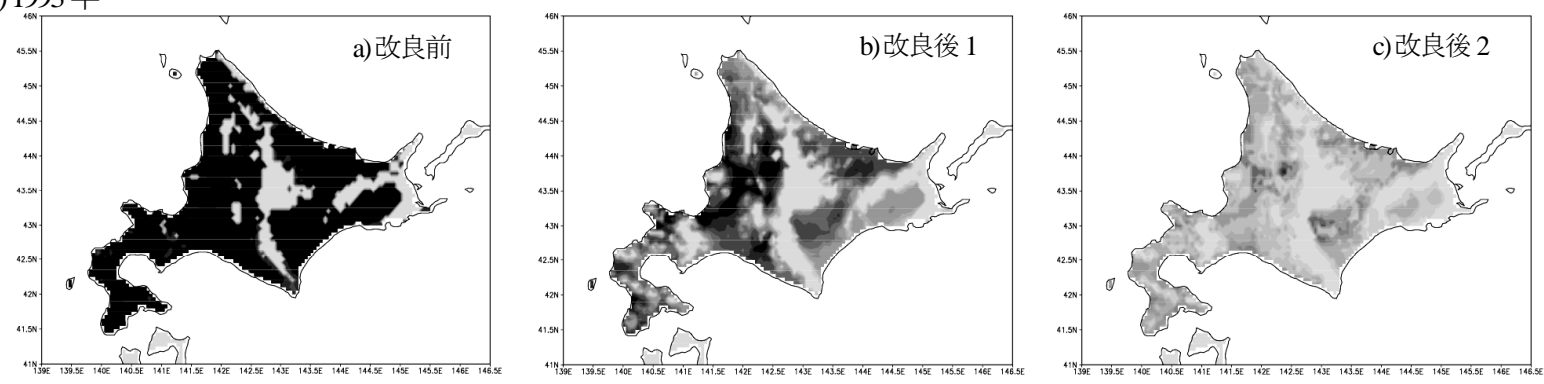

(2) 2000 年
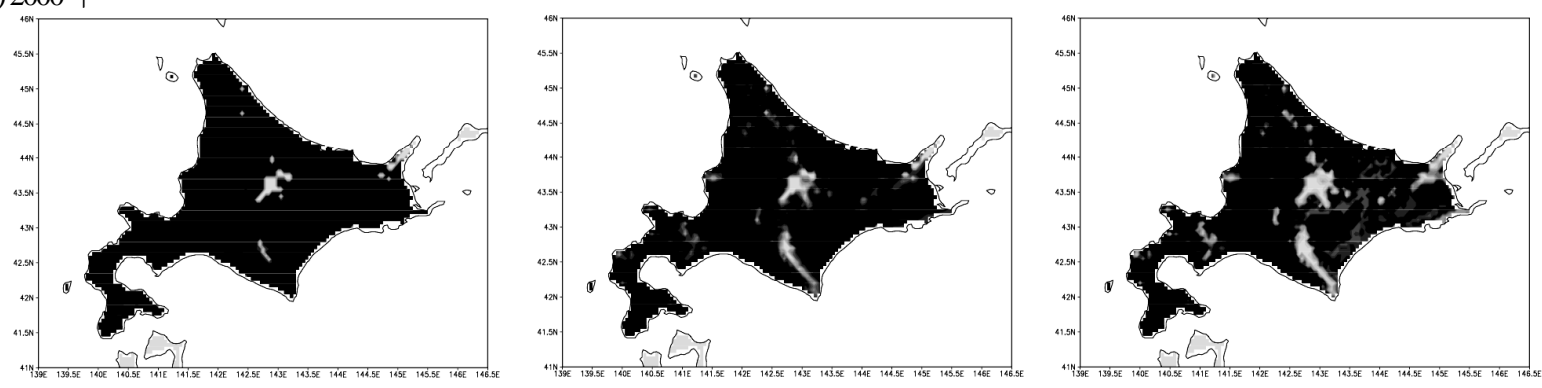

$\begin{array}{llllllllllll}0 & 500 & 1000 & 1500 & 2500 & 3000 & 3500 & 4000 & 4500 & 5000 & 5500 & 6000\end{array}$

[kg/ha]

図-4 1993年，2000年における改良前・改良後1・改良後2の収量ポテンシャル計算結果
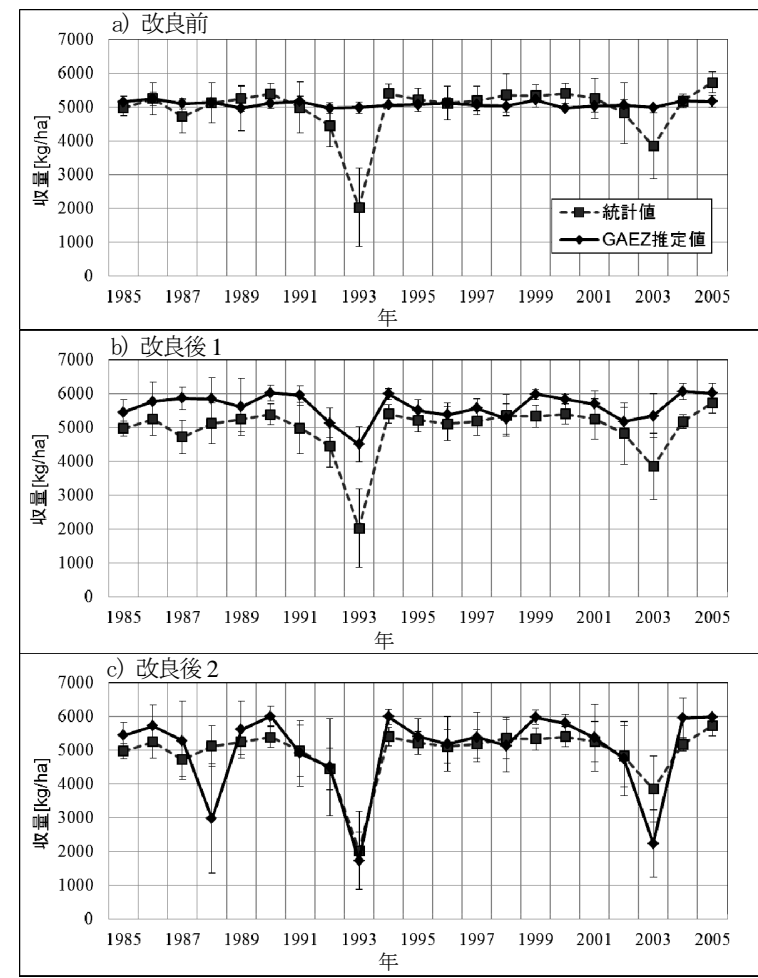

図-5 GAEZ改良前, 改良後1, 改良後2の北海道全域平均収 量の観測との比較. エラーバーは収量標準偏差で, GAEZは格子単位，統計值は市町村単位である.

れた. (3)では, 出穂遅延による成熟期間の短縮の考慮 (end期間の比の乗算) により観測収量の再現性が向上
表-5 GAEZによる北海道全域平均収量の観測との比較. MBEは平均誤差，RMSEは二乗平均平方根誤差，Rは 相関係数.**は1\%危険率で有意な相関であることを 示寸.

\begin{tabular}{l|lll}
\hline & 改良前 & 改良後 1 & 改良後 2 \\
\hline MBE [kg/ha] & 128.51 & 665.86 & 65.03 \\
RMSE [kg/ha] & 742.40 & 848.73 & 701.11 \\
R & 0.390 & $0.768^{* *}$ & $0.835^{* *}$ \\
\hline
\end{tabular}

した. (4)の実施により観測収量の再現性は大幅に向上 した。(1)は栽培適性判定に関する変更で，(2)および(3) は日々の気象条件を収量計算に反映するための改良, (4)は障害型冷害の考慮により障害リスクを収量に反映 する改良と大きく分けられることから，以降では(1)の み実施した場合を「改良前」，(1)（3)を実施した場合 を「改良後1」，(1)（4)を実施した場合を「改良後2」と して結果を述べる.

図-4は記録的な冷害となった1993年と平年以上の収量 となった2000年におけるGAEZモデルの改良前・改良後 1 ・改良後2での収量ポテンシャル計算結果である. 改 良前と比較し改良後は両年とも地域差が拡大している. また，改良後は両年の収量ポテンシャルの差が大きくな っている. 改良後1で収量減少がみられる地域は出穂遅 延によるもので, 改良後2で収量減少がみられる地域は 出穂遅延に加えて障害型冷害の影響を受けたことを示し 


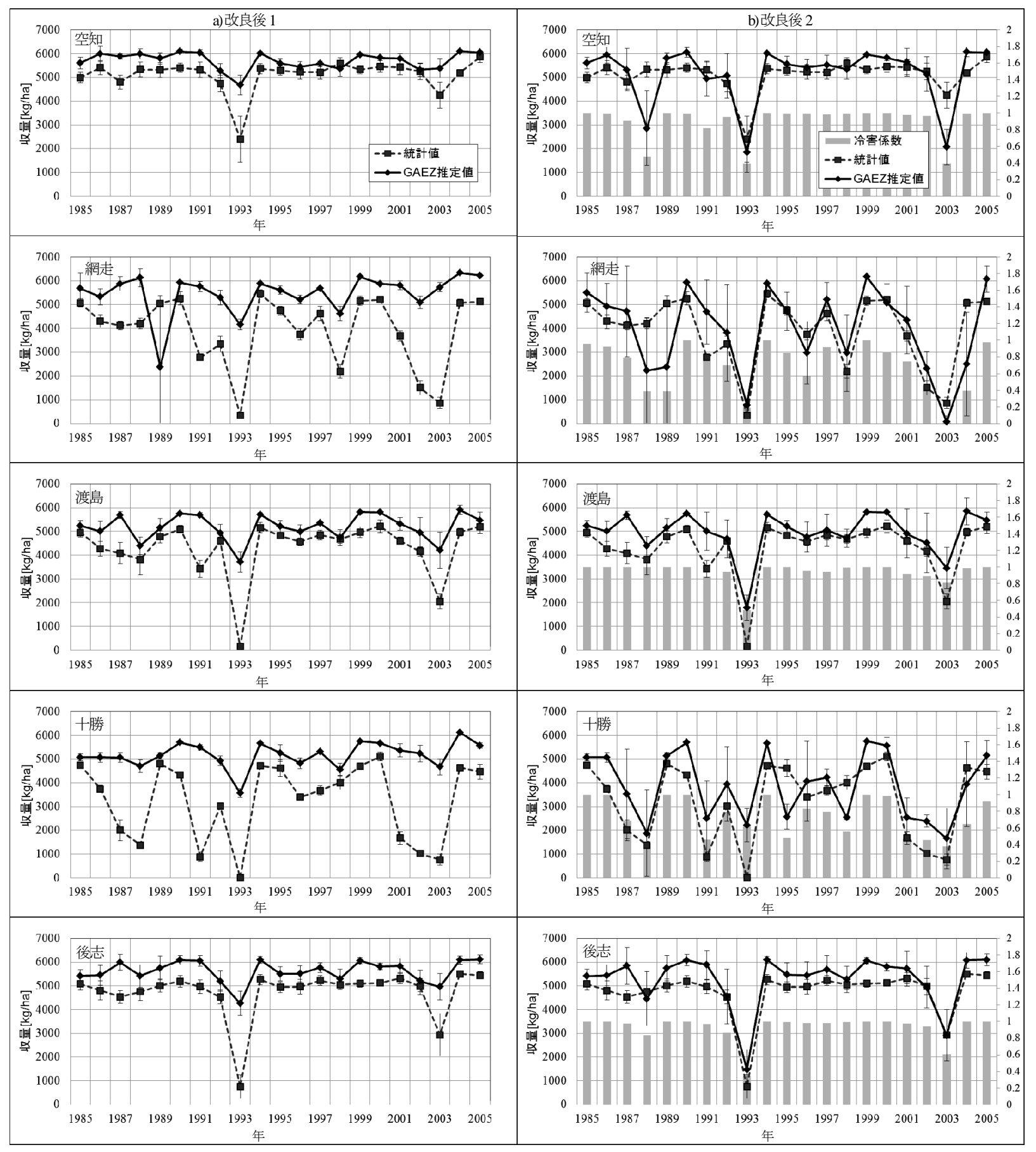

図-6 GAEZの改良後1, 改良後2の支庁平均収量の観測収量との比較. 上から空知（北海道中央内陸部）, 網走（東部才ホー ツク海側）, 渡島（南部太平洋側），十勝（東部太平洋側），後志支庁（西部日本海側）。改良後2は障害型の泠害係 数を棒グラフで示している.

ており，1993年で顕著である.

以降は作付地域で集計した值を用いて観測収量との比 較を行う。図-5は改良前，改良後1，改良後2における北 海道全域平均収量の比較結果である. 改良前は観測の収 量変動をほとんど再現しないのに対し，改良後1では収 量は過大となるが変動の再現性は向上する. 先述の通り, 過大傾向は主にバイオマス生産率の計算式変更によるも のである. 変更はバイオマス生産率計算のための日射量
の計算方法に対して行ったことから，日射量の処理方法 については今後精緻化が必要である. 変動の再現性向上 は出穂遅延による成熟期間短縮の効果を考慮したことの 寄与が大きく，併行型の冷害といわれる1992年，1993年， 2002年，2003年 (北海道ほか ${ }^{24)}$ ) で収量にやや落ち込み がみられる。しかし，1993年や2003年などの大幅な収量 減少は再現しきれておらず，2002年や2003年の収量減少 は冷害のなかった1998年の収量と同程度となっている. 
表-6 GAEZ収量と観測の支庁別 - 市町村別比較. MBE，RMSE，Rは作付地域のない3支庁を除く11 支庁の平均. $1 \%$ 危険率で有意な相関となる市町 村数は1985〜2005年全てで収量がゼロではない市 町村のみについて集計した。

\begin{tabular}{l|lll}
\hline & 改良前 & 改良後 1 & 改良後 2 \\
\hline MBE [kg/ha] & 569.71 & 934.24 & 258.01 \\
RMSE [kg/ha] & 1217.84 & 1238.56 & 899.11 \\
R & 0.420 & $0.695 * *$ & $0.814^{* *}$ \\
$\begin{array}{l}\text { 1\%危険率で有 } \\
\text { 意な相関 とな }\end{array}$ & $15 / 110$ & $101 / 110$ & $106 / 110$ \\
る市町村数 & & & \\
\hline
\end{tabular}

障害型冷害を考慮した改良後2ではこれら併行型の冷害 時の収量減少を再現し, 変動の再現性がさらに向上寸る

（表-5）。また，障害型の冷害といわれる1987年（北海 道ほか24)）で改良後1と比較し収量の減少がみられるよ うになった．以上より北海道の観測収量変動の再現には 障害型冷害の考慮が特に重要であることが分かった．障 害型冷害は出穂日を基準とした特定期間の気温条件に基 づき推定していることから，適確な出穂日を推定するこ とも重要であると考えられる.

本研究の結果から, 気温条件のみから推定した障害型 冷害の影響によって北海道におけるコメ収量の冷害影響 を概ね再現可能であることが分かった。これは北海道の コメの品種が感温性の高い性質を持つことによる（北海 道ほか ${ }^{25)}$ ) と考えられる。一方，1988年には観測にはな い収量の大幅な減少が計算され，逆に2003年の冷害時の 収量減少は過大評価となっている. 出穂日の推定值の統 計值との誤差は2003年の函館地域で約3.2日，1988年の北 見地域で約2.2日であるが大幅な誤差ではなく, 出穂日 のずれが障害型冷害推定の誤差に寄与したとは考えにく い. 不稔発生の多少は昼夜の気温差やその継続日数, 日 照時間，品種の耐冷性，稲体の窒素濃度などにより变わ るといわれており (北海道ほか24) ${ }^{24}$ ，再現性悪化の要 因はこれらの要素を考慮していないことによる可能性が あると考えられる。

図-6に改良後1および改良後2の支庁平均での観測収量 との比較結果を示寸．観測の収量変動は地域による差が 大きく, 網走地方や十勝地方では年ごとの変動が大きい のに対し，空知地方や上川地方 (図略) では安定してお り，渡島地方や後志地方などは両者の中間的な特徵を持 つ. 出穂遅延の影響を考慮した改良後1では収量の変動 は良く再現しており，市町村別にみても再現性は大きく 向上する（表-6）。観測ほど変動に地域差はみられない が，空知や後志と比較し網走，渡島，十勝地方では変動
幅がやや大きくなっており, 出穂遅延による成熟不良の

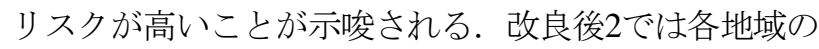
冷害時の収量減少幅や頻度を良く再現し，地域差を非常 に良く再現している. 改良後2は改良後1にさらに障害型 冷害を考慮した状態であることから，北海道の収量変動 の地域差をもたらす要因として障害型の冷害が関係して いることが示唆される. 障害型冷害の収量変動への寄与 の大きさは冷害係数と改良後2の収量変動がほぼ同期し ていることからも推測できる. 網走地方や十勝地方は冷 害係数の変動が大きく，障害型冷害のリスクが高いのに 対し, 空知や渡島, 後志地方では係数がほぼ1で安定し ており, リスクが低いことが示唆される. 網走地方や十 勝地方では先述の通り出穂遅延の影響も受けや寸く, 冷 害リスクが非常に高い地域であることが示唆される.

\section{5. まとめ}

本研究では, 広域スケールの潜在作物生産性モデルで あるGAEZを北海道へ適用するためにモデルの改良を実 施し, 改良前と改良後て観測のコメ収量変動の再現性を 評価した. GAEZモデルにおける日本型イネの適性判定 条件では，多くの年に北海道のほぼ全域で低温の条件を 満たさず収量がゼロとなったことから，広域モデルをそ のまま北海道には適用できないことが分かった。しかし， 適性判定条件を撤廃し，さらにバイオマス計算論理の変 更, 出穂日推定論理の追加, そして障害型冷害推定論理 の追加を行うことで観測収量変動の再現性が大幅に向上 した.

まず，バイオマス量の計算のためLAIを作物係数から 推定し，簡易有効積算気温から推定した出穗日による LAIの変動と出穂遅延による成熟不良を考慮した場合, 観測収量変動の再現性は向上するが冷害時の大幅な収量 減少は再現しなかった，さらに，出穗日を基準とした特 定期間の気温条件により障害型冷害の影響を推定し反映 したところ，観測収量の再現性は大幅に向上した。この ことから, 北海道の観測収量変動の再現には障害型冷害 の考慮とそのための出穗日の推定が特に重要であること が分かった．また，障害型冷害の考慮により北海道内の 収量変動の地域差も非常に良く再現できるようになった ことから, 収量変動の地域差をもたらす要因として障害 型の冷害が関係していると考えられた。本研究では出穂 日の推定およひ障害型冷害の推定は気温条件のみに基づ いているため, 北海道のコメ収量変動は気温条件で概ね 説明できることが示された。 これは北海道のコメ品種が 感温性の高い性質を持つことによるものと考えられる. 本研究でGAEZモデルの改良を行う際，北海道固有の 
パラメータとして新たに用いたのは出穂日までの簡易有 効積算気温（道内で2地域に分類），品種の成長期間 （耕種期日の統計值より推定），作物長，および障害型 冷害の不稔歩合のみであり，これらは公表されているデ 一タに基づいている. 本結果から, 比較的容易なチュー ニングにより冷害も含めた変動を再現可能であることが 分かった，北海道において主要な障害である冷害リスク を評価できるようになったことで, 現在および将来の北 海道におけるより信頼性の高い影響評価が可能になると 考える.

一方で, 冷害に関して課題も残されている. 本研究で は遅延型冷害として出穂遅延による登熟期間の短縮を考 慮し, 観測の収量変動と有意な相関が得られた。しかし, 実際には出穂遅延のため秋冷により登熟不良となる場合 や, 出穂が遅延しなくても登熟期の低温により登熟不良 となる場合に遅延型の冷害が発生する（北海道ほか 24)）。このため, 低温による登熟割合への影響の考虑 が必要となる可能性があり，さらなる検討が必要である。 本研究は気候変動による北海道のコメ収量変動への影 響評価を行う前段階として, 現在気候下でのGAEZモデ ルの適用可能性を確認した. その結果, モデル改良によ り北海道における収量変動を再現可能であることが示さ れたが，今後将来気候に適用寸る際にいくつかの課題が 挙げられる. 本研究では冷害影響は考慮したが高温障害 の影響は考慮していない. 北海道の気候がイネの高温障 害に影響を及ぼすほど変化する場合には，モデルに高温 障害の論理を組み込む必要がある。また，本研究では $\mathrm{CO}_{2}$ の施肥効果を考慮しなかった。気候変動だけでなく, $\mathrm{CO}_{2}$ 濃度の増加に伴い収量にどの程度の影響があるのか 検討する必要がある.

GAEZモデルでは灌溉地域は水ストレスを受けないと 仮定している. しかし, 将来の気候変動により融雪が早 期化し, 必要な時期に十分な灌溉用水を確保できなくな る可能性も否定できないため, 水ストレスの仮定につい てさらなる検討が必要になると考えられる.

謝辞 : 著者は，グローバルCOEプログラム「統合フィー ルド環境科学の教育研究拠点形成」のリサーチアシスタ ントとして支援を受けた。 WRFによるダウンスケール は, 環境省環境研究総合推進費 (S-8-1(2)) により実施 された.

\section{参考文献}

1) Easterling, W.E., Aggarwal P.K., Batima P., Brander K.M., Erda L, Howden S.M., Kirilenko A., Morton J., Soussana J., Schmidhuber J. and Tubiello F.N.: Food, fibre and forest products, In: Parry M.L., Canziani O.F.,
Palutikof J.P.,Vander Linden P.J., Hanson C.E.(Eds.): Climate Change 2007: Impacts, Adaptation and Vulnerability. Contribution of Working Group II to the Fourth Assessment Report of the Intergovemmental Panel on Climate Change, Cambridge University Press, Cambridge, UK., 2007.

2) Masutomi Y., Takahashi K., Harasawa H. and Matsuoka Y.: Impact assessment of climate change on rice production in Asia in comprehensive consideration of process/parameter uncertainty in general circulation models, Agriculture, Ecosystems and Environment, Vol. 131, pp. 281-291, 2009.

3) 申龍熙, 高橋潔, 肱岡靖明, 花崎直太, 山本隆広, 増冨祐 司 : 気候予測の不確実性を考慮した世界のトウモロコシ生 産性の温暖化影響評価，土木学会論文集 G（環境），Vol.67, No.5,pp.I_61-I_70,2011.

4) 横沢正幸, 飯泉仁之直, 岡田将誌 : 気候変化がわが国におけ るコメ収量変動に及ぼす影響の広域評価, 地球環境, Vol. 14, No. 2, pp. 199-206, 2009.

5) Fischer G., van Veldhuizen H., Shah M. and Nachtergaele F.O.: Global Agroecological Assessment for Agriculture in the 21st Century: Methodology and Results, IIASARR-02-02, IIASA, Laxenburg, Austria, 2002.

6) 清野豁 : アメダスデータのメッシュ化について, 農業気象, Vol. 48, No. 4, pp. 379-383, 1993.

7) Onogi K., Tsutsui J., Koide H., Sakamoto M., Kobayashi S., Hatsushika H., Matsumoto T., Yamazaki N., Kamahori H., Takahashi K., Kadokura S., Wada K., Kato K., Oyama R., Ose T., Mannoji N. and Taira R.: The JRA25 Reanalysis, J. Meteor. Soc. Japan, Vol. 85, pp. 369-432, 2007.

8) Skamarock W.C., Klemp J.B., Dudhia J., Barker D.M., Duda M.G., Huang X.-Y., Wang W. and Powers J.G.: A description of the Advanced Research WRF version 3, Tech. Note NCAR/N-475+STR, Natl. Cent. for Atmos. Res., Boulder, Colo, 113pp., 2008.

9) 国土交通省：国土数值情報（行政区域）.

10) FAO: Digital Soil Map of the World (Version 3.5), Food and Agriculture Organization Press, Rome, Italy, 1995.

11) USGS: GTOPO30, United States Geological Survey; http://www1.gsi.go.jp/geowww/globalmap-gsi/gtopo30/gtopo30.html

12) 農林水産省農林経済局統計調査部：作物統計； http://www.maff.go.jp/j/tokei/kouhyou/sityo_tyouki/

13)農林水産省農林経済局統計調查部 : 作物統計.

14) 農林水産省北海道統計情報事務所 [編集] : 北海道農林水産 統計年報. 農業統計市町村別編.

15) 国土交通省 : 国土数值情報（土地利用 3 次メッシュ）.

16) World Bank: World Development Indicators 2006, World Bank, Washington, CD-ROM, 2006.

17) 農林水産省農林経済局統計調査部 : 作物統計 ; http:/www.estat.go.jp/SG1/estat/GL08020103.do?_toGL08020103_\&listID=00000106 9790\&requestSender=dsearch

18) Fischer G., van Velthuizen H., Serge M. and Nachtergaele F.: Global Agro-ecological Assessment for Agriculture in the 21st Century CD-ROM: 
APPENDIX VI BIOMASS AND YIELD CALCULATION;

http://www.iiasa.ac.at/Research/LUC/SAEZ/index.html

19) Allen R.G., Pereira L.S., Raes D., Smith M: Crop evapotranspiration -

Guidelines for computing crop water requirements - FAO Irrigation and drainage paper 56: Chapter 7 - ETc - Dual crop coefficient (Kc $=K c b+$ $\mathrm{Ke}$ ), Food and Agriculture Organization of the United Nations, Rome, Italy, 1998; http:/www.fao.org/docrep/X0490E/x0490e00.htm

20) 桜谷哲夫, 堀江武 : 作物の蒸発散に関する研究 (1) 水田蒸発 散の季節・品種別特性と簡易推定法, 農業気象, Vol. 41, No. 1, pp. 45-55, 1985

21) 北海道立総合研究機構 農業研究本部 中央農業試験場 : 平成 21 年度 北海道立中央農業試験場年報.

22) 丹野久, 田中英彦，古原洋，佐々木亮，三浦周 : 寒地水稲 の湛水土中直播栽培における簡易有効積算気温による品種 選定，日作紀，Vol. 76, No.4,pp. 591-599, 2007.
23) 北海道, 道総研農業研究本部，ホクレン農業協同組合連合 会, 社団法人 北海道米麦改良協会 : 北海道の米づくり [2011 年版] : III. 水稲地帯別作付け指標之品種特性 ; http:/www.beibaku.net/rice/2011/manual/ricetext/ricetext_05.pdf

24) 北海道, 道総研農業研究本部，ホクレン農業協同組合連合 会, 社団法人 北海道米麦改良協会 : 北海道の米づくり [2011 年版 ] : IX. 冷害の発生と対策; http:/www.beibaku.net/rice/2011/manual/ricetext/ricetext_11.pdf

25) 北海道, 道総研農業研究本部，ホクレン農業協同組合連合 会, 社団法人 北海道米麦改良協会 : 北海道の米づくり [2011 年版] : II. 北海道稲作の生い立ちと水稲生育の特徵 ; http://www.beibaku.net/rice/2011/manual/ricetext/ricetext_04.pdf

(2012.4. 3 受付)

(2012.7.7 受理)

\title{
Assessment and Improvement of the Global Agro-Ecological Zones Model for Estimation of Rice Productivity in Hokkaido
}

\author{
Akemi TANAKA ${ }^{1}$, Kiyoshi TAKAHASHI ${ }^{2}$, Yonghee SHIN $^{2}$, Yuji MASUTOMI ${ }^{3}$, \\ Yasuhiro YAMANAKA ${ }^{4}$ and Tomonori SATO ${ }^{4}$ \\ ${ }^{1}$ Graduate School of Environmental Science, Hokkaido University \\ ${ }^{2}$ Center for Social and Environmental Systems Research, National Institute for Environmental Studies \\ ${ }^{3}$ Global Warming Research Lab., Center for Environmental Science in Saitama \\ ${ }^{4}$ Faculty of Environmental Earth Science, Hokkaido University
}

We assessed possibility of the Global Agro-Ecological Zones (GAEZ) model for applying to rice productivity in Hokkaido, Japan, and improved it in order to simulate rice yield change responding to climate in Hokkaido. Before improving GAEZ model, the simulated yield was almost zero in most of the calculated periods, which means, the original GAEZ model is not applicable to Hokkaido where strengthening cool tolerance of rice variety has been developed. We improved four points: (1) easing temperature requirement, (2) modifying biomass calculation, (3) predicting heading date and (4) predicting cool summer damage due to floral impotency. The improvement of (1) enables GAEZ model to apply for cold regions; but, it did not simulate the observed yield variation. A simulation with combination of (1), (2), (3) and (4) simulated the variation of observed data. Especially, taking account of cool summer damage due to floral impotency and predicting heading date contribute to more accurate simulation of the observed yield variation. 